\title{
Adoption of Scientifically Recommended Artificial Insemination Practices by Paravets: A Depiction of Current Scenario of Four States in India
}

PRATIKSHYA PANDA ( $\sim$ pratikshya.pandavet@gmail.com )

Indian Veterinary Research Institute https://orcid.org/0000-0001-5488-1008

\section{Rupasi Tiwari}

ICAR-Indian Veterinary Research Institute: Indian Veterinary Research Institute

Pragya Joshi

Indian Veterinary Research Institute

Amandeep Singh

Guru Angad Dev Veterinary and Animal Sciences University

Triveni Dutt

ICAR-Indian Veterinary Research Institute: Indian Veterinary Research Institute

\section{Research Article}

Keywords: Paravets, artificial insemination, adoption gap, crystoscope, sanitary measures

Posted Date: July 6th, 2021

DOl: https://doi.org/10.21203/rs.3.rs-659593/v1

License: (9) This work is licensed under a Creative Commons Attribution 4.0 International License. Read Full License 


\section{Abstract}

The present investigation was done to assess the different practices followed by the Al technicians (paravets) while performing Artificial Insemination (AI). A total of 160 paravets were selected for the study having equal representation from 4 different states of India (Gujarat, Rajasthan, Telangana and Odisha). Questionnaire and telephonic survey was used for collecting data. Several practices followed by paravets were assessed under three sub-groups viz., practices followed prior to, during and post-artificial insemination. In as many as seven practices viz., gathering pre Al information, storage of semen straw, time of performing Al, thawing container, wiping of semen straw, cutting of semen straw and record keeping the adoption gap was found to be Nil. Maximum adoption gap (30.60 \%) was seen in 'adopting basic sanitary measures'. Whereas about 13 percent of adoption gap was found in case of 'monitoring of heat post calving' followed by 'checking of heat prior to Al' (8.00\%). Hence, along with provision of necessary measures for water bath, apron and gumboots by State Department of Animal Husbandry (SDAH), the paravets should be made aware about the importance of basic sanitary measures. Crystoscope availability should also be ensured as it is easy to use by paravets and farmers for heat detection.

\section{Introduction}

Livestock being an integral and irreplaceable part of the agriculture production system, plays a crucial role in the development of India's economy. Though the sector contributes $4.1 \%$ to total GDP and around 1/3rd i.e. $27.4 \%$ to agricultural GDP, the major limiting factor faced by it is due low productivity (BAHS, 2019, DAHD, Gol). In India, artificial insemination (Al) is generally performed by Al technicians (paravets). As per the reports of (Farmers' Manual, DAHD\&F, Gol), there are several factors which hinder in success rate of $\mathrm{Al}$ and also restrain in quality service delivery such as wrong $\mathrm{Al}$ technique may lead to conception failure and hence requires well trained inseminators for successful Al. Repeat breeding, poor conception, improper heat detection, incorrect handling of semen and unavailability of trained technicians are some of the most important constraints in breeding sector (Hamdani, 2013; Eklundh and Camilla, 2013; Ibrahim et al., 2014; Lawrence et al., 2015). This indicated how knowledge gaps and improper practices threatens the outcome of Al and thereby also affect the extent of the adoption of Al. Capacity of Al technician (paravets) and insemination technique are also the major role players for poor fertility (Shamsuddin et al., 1997). A number of practices such as rectal palpation, checking of soft cervix, thawing temperature, straw cutting method and semen deposition) too have a significant impact on the success of Al (Ybañez et al., 2017). It is also reported that paravets delivering livestock services had medium to low knowledge level in breeding aspects and there is a need to fulfil the knowledge gap to have an impact on overall quality of service (Hamdani, 2013). An Artificial Insemination (Al) service following Standard Operating Procedures (SOPs) and being delivered at the doorstep of animal owners is crucial to effective animal breeding activities. According to 20th Livestock Census, Govt. of India, total adult female bovine population in India is 133.3 million. But only 20 per cent of the breed-able bovine population is under Al coverage and the rest of the 80 per cent of the breed-able bovines are covered through natural service 
(Annual Report, 2019-20, DAHD\&F). This is leading to deterioration in the performance and productivity of cattle. So Government of India is giving utmost importance to strengthen the animal breeding prospects through effective Al services. Hence, a revolutionary step has been taken by government of India to increase the Al coverage through Nationwide Artificial Insemination Program (NAIP). Keeping these facts under consideration, there was an urgent need to study the practices/steps followed by paravets/AI technicians while performing artificial insemination.

\section{Materials And Method}

The study was conducted in four states of India viz., Rajasthan, Gujarat, Telangana and Odisha. From each states, three districts were purposively selected as per the accessibility of the researcher. The selected districts from Rajasthan were Jaipur, Sikkar and Jhunjhunu; districts selected from Odisha were Nabarangpur, Balasore and Dhenkanal; from Telangana the districts selected were Mahbubnagar, Warangal and Khamam whereas from Gujarat, Kutch, Banaskanta and Anand were selected. Sample for the study were paravets/Al technicians of the respective areas actively involved in artificial insemination under state animal husbandry departments. Questionnaire and telephonic survey methods were used to collect data.

A total of 400 questionnaires viz., 100 to each state were mailed to the respondents residing in the study areas keeping in view the response rate of questionnaire (30-40\%). There were 180 filled questionnaires returned back from which 40 were incomplete. Telephonic survey was used for gathering the complete data from those which returned incomplete/partially filled. Forty paravets were randomly selected from each state making a total sample of 160 paravets.

Keeping in view the SOPs for artificial insemination, a total of fourteen practices were enlisted under 3 sub-heads viz., practices followed 'prior to artificial insemination', 'during the actual execution of artificial insemination' and 'post artificial insemination'. The respondents were given score (1) for each adopted practice and score ( 0 ) for practice not adopted. Adoption level for each practices was calculated as percentage score using the following formula. Similarly adoption gap was estimated

\section{Adoption Score $=\sum_{1}^{n} \frac{X_{i j}}{Y_{i j}} \times 100$}

Where, $\mathrm{n}=$ Total number of respondents

$X_{i j}=$ Obtained score of $\mathrm{i}^{\text {th }}$ practice by $\mathrm{j}^{\text {th }}$ respondent

$Y_{i j}=$ Maximum obtainable score of $\mathrm{i}^{\text {th }}$ practice by $\mathrm{j}^{\text {th }}$ respondent

Data analysis was done by use of statistical software SPSS to calculate the frequency, percentage, mean, standard error. Comparison among groups was done by one way ANOVA. 


\section{Results}

\subsection{Socio-Personal and Socio-Economic Profile of paravets}

The results given in table. 1 gives the information about socio-personal and socio-economic profile of the respondents which includes age, gender, educational qualification, family background, job experience, number of trainings undergone and average annual income.

\subsubsection{Age}

From the results it is evident that a large proportion (65.0\%) of the total number of respondents was from Young age group of 21 to 32 years followed by middle age group viz., $21.9 \%$. Significant difference ( $p<$ 0.05 ) was found among the four states with regards to age of Paravets. Respondents of the Telangana state had a significantly higher average age as compared to other states with an average age of 35.05 years. The average age of the total sample was 32.06 years.

\subsubsection{Gender}

Of the total sample, $95 \%$ were male and only $5 \%$ of them were female. Among the respondents of four states, Rajasthan was having highest number of female i.e. $10 \%$ as compared to other 3 states followed by Gujarat with $7.50 \%$ female who were working as paravets.

\subsubsection{Educational qualification}

Among the total sample, $76.25 \%$ paravets had educational qualification upto intermediate and $23.75 \%$ were graduate and above. Proportion of respondents having qualification of Graduate and above was more (35.00 \%) in case of Rajasthan.

\subsubsection{Family background}

Results from the pooled sample reveal that most of the paravets $(70.0 \%)$ were from rural background followed by semi-urban (15.0\%) and urban (14.4\%) background.

\subsubsection{Job experience}

Among the total number of respondents, majority (81.30\%) were having low experience in Al ranging from 1 to 10 years. No significant difference was found among the states. The average experience of the respondents was 6.97 years.

\subsubsection{Number of training undergone}

The respondents were asked about the number of trainings undergone on Al in their work period. Results indicated that maximum number of respondents ( $43.75 \%$ ) had undergone one training followed by 36.25 $\%$ who had undergone two trainings on Al. Among the number of respondents who had undergone two trainings, the respondents of Rajasthan were more i.e. $42.50 \%$.

\subsubsection{Annual income}


Respondents were asked about their Annual Income per year. Results reveal that the Average Annual Income of the sample was 2.87 lakhs with a comparatively higher average Annual Income in Telangana state. 
Table 1

Socio-personal and socio-economic profile of Al technicians (paravets)

\begin{tabular}{|c|c|c|c|c|c|}
\hline $\begin{array}{l}\text { Socio-Personal and socio- } \\
\text { economic profile }\end{array}$ & $\begin{array}{l}\text { Gujarat } \\
(n=40)\end{array}$ & $\begin{array}{l}\text { Rajasthan } \\
(n=40)\end{array}$ & $\begin{array}{l}\text { Odisha } \\
(n=40)\end{array}$ & $\begin{array}{l}\text { Telangana } \\
(n=40)\end{array}$ & $\begin{array}{l}\text { Pooled }(\mathrm{N} \\
=160)\end{array}$ \\
\hline \multicolumn{6}{|l|}{ Age (In Years) } \\
\hline Young & 27 & 30 & 23 & 24 & 104 \\
\hline$(21-32)$ & $(67.50)$ & $(75.00)$ & $(57.50)$ & $(60.00)$ & $(65.00)$ \\
\hline Middle & 8 & 5 & 12 & 10 & 35 \\
\hline$(33-44)$ & $(20.00)$ & $(12.50)$ & $(30.00)$ & $(25.00)$ & $(21.90)$ \\
\hline Old & 5 & 5 & 5 & 6 & 21 \\
\hline$(45-55)$ & $(12.50)$ & $(12.50)$ & $(12.50)$ & $(15.00)$ & $(13.10)$ \\
\hline Mean \pm SE & $\begin{array}{l}30.5^{\mathrm{a}} \pm \\
1.4\end{array}$ & $29.28^{\mathrm{a}} \pm 1.4$ & $\begin{array}{l}33.07^{\mathrm{ab}} \pm \\
1.3\end{array}$ & $35.05^{b} \pm 1.2$ & $\begin{array}{l}32.06 \pm \\
0.68\end{array}$ \\
\hline \multicolumn{6}{|l|}{ F Value $3.56^{*}$} \\
\hline \multicolumn{6}{|l|}{ Gender } \\
\hline \multirow[t]{2}{*}{ Male } & 37 & 36 & 39 & 40 & 152 \\
\hline & $(92.50)$ & $(90.00)$ & $(97.50)$ & $(100.00)$ & $(95.00)$ \\
\hline \multirow[t]{2}{*}{ Female } & 3 & 4 & 1 & 0 & 8 \\
\hline & $(7.50)$ & $(10.00)$ & $(2.50)$ & $(0.00)$ & $(5.00)$ \\
\hline \multicolumn{6}{|l|}{ Educational qualification } \\
\hline \multirow[t]{2}{*}{ Intermediate } & 33 & 26 & 36 & 27 & 122 \\
\hline & $(82.50)$ & $(65.00)$ & $(90.00)$ & $(67.50)$ & $(76.25)$ \\
\hline \multirow[t]{2}{*}{ Graduate and above } & 7 & 14 & 4 & 13 & 38 \\
\hline & $(17.50)$ & $(35.00)$ & $(10.00)$ & $(32.50)$ & $(23.75)$ \\
\hline \multicolumn{6}{|l|}{ Family Background } \\
\hline \multirow[t]{2}{*}{ Rural } & 30 & 27 & 33 & 23 & 113 \\
\hline & $(75.00)$ & $(67.50)$ & $(82.50)$ & $(57.50)$ & $(70.60)$ \\
\hline \multirow[t]{2}{*}{ Semi-urban } & 1 & 6 & 4 & 13 & 24 \\
\hline & $(2.50)$ & $(15.00)$ & $(10.00)$ & $(32.50)$ & $(15.00)$ \\
\hline
\end{tabular}




\begin{tabular}{|c|c|c|c|c|c|}
\hline $\begin{array}{l}\text { Socio-Personal and socio- } \\
\text { economic profile }\end{array}$ & $\begin{array}{l}\text { Gujarat } \\
(n=40)\end{array}$ & $\begin{array}{l}\text { Rajasthan } \\
(n=40)\end{array}$ & $\begin{array}{l}\text { Odisha } \\
(n=40)\end{array}$ & $\begin{array}{l}\text { Telangana } \\
(n=40)\end{array}$ & $\begin{array}{l}\text { Pooled }(\mathrm{N} \\
=160)\end{array}$ \\
\hline \multirow[t]{2}{*}{ Urban } & 9 & 7 & 3 & 4 & 23 \\
\hline & $(22.50)$ & $(17.50)$ & $(7.50)$ & $(10.00)$ & $(14.40)$ \\
\hline \multicolumn{6}{|l|}{ Job Experience } \\
\hline Low & 33 & 36 & 31 & 30 & 130 \\
\hline$(1-10)$ & $(82.50)$ & $(90.00)$ & $(77.50)$ & $(75.00)$ & $(81.30)$ \\
\hline Medium & 3 & 0 & 7 & 9 & 19 \\
\hline$(11-20)$ & $(7.50)$ & $(0.00)$ & $(17.50)$ & $(22.50)$ & $(11.90)$ \\
\hline High & 4 & 4 & 2 & 1 & 11 \\
\hline$(21-30)$ & $(10.00)$ & $(10.00)$ & $(5.00)$ & $(2.50)$ & $(6.90)$ \\
\hline Mean \pm SE & $\begin{array}{l}6.60 \pm \\
1.22\end{array}$ & $5.58 \pm 1.26$ & $\begin{array}{l}7.25 \pm \\
1.18\end{array}$ & $8.45 \pm 0.84$ & $6.97 \pm 0.57$ \\
\hline \multicolumn{6}{|c|}{ Number of training undergone } \\
\hline \multirow[t]{2}{*}{ One } & 18 & 18 & 20 & 14 & 70 \\
\hline & $(45.00)$ & $(45.00)$ & $(50.00)$ & $(35.00)$ & $(43.75)$ \\
\hline \multirow[t]{2}{*}{ Two } & 14 & 16 & 14 & $14(35.00)$ & 58 \\
\hline & $(35.00)$ & $(42.50)$ & $(35.00)$ & & $(36.25)$ \\
\hline \multirow[t]{2}{*}{ Three } & 6 & 5 & 4 & 10 & $25(15.62)$ \\
\hline & $(15.00)$ & (12.50) & $(10.00)$ & $(25.00)$ & \\
\hline \multirow[t]{2}{*}{ Four } & 2 & 1 & 2 & 2 & $7(4.37)$ \\
\hline & $(5.00)$ & $(2.50)$ & $(5.00)$ & $(5.00)$ & \\
\hline
\end{tabular}

(Figures in parenthesis indicate percentage)

\subsection{Practices followed by paravets while performing Al 3.2.1. Practices followed prior to Artificial Insemination}

Prior to the actual conduction of $\mathrm{Al}$, it is a standard recommended practice to check, if the animal was in heat or not and gather various information about Al. Further, proper storage and handling of semen straw for the preservation of semen so that the sperms remain viable and don't lose their motility is also an important practice before actual execution of Al. Results of the study presented in the Table 2 revealed that for checking heat prior to Al, majority of paravets (81.2\%) followed both external signs and per rectal examination followed by observing only external signs (16.25\%). A wholesome proportion of 
respondents $(65.0 \%)$ asked about time of heat as pre-Al information. In case of storage of semen straw, cent percent of the paravets stored the semen straw in Cryocan.

Table 2

Distribution of respondents according to practices followed prior to Artificial insemination

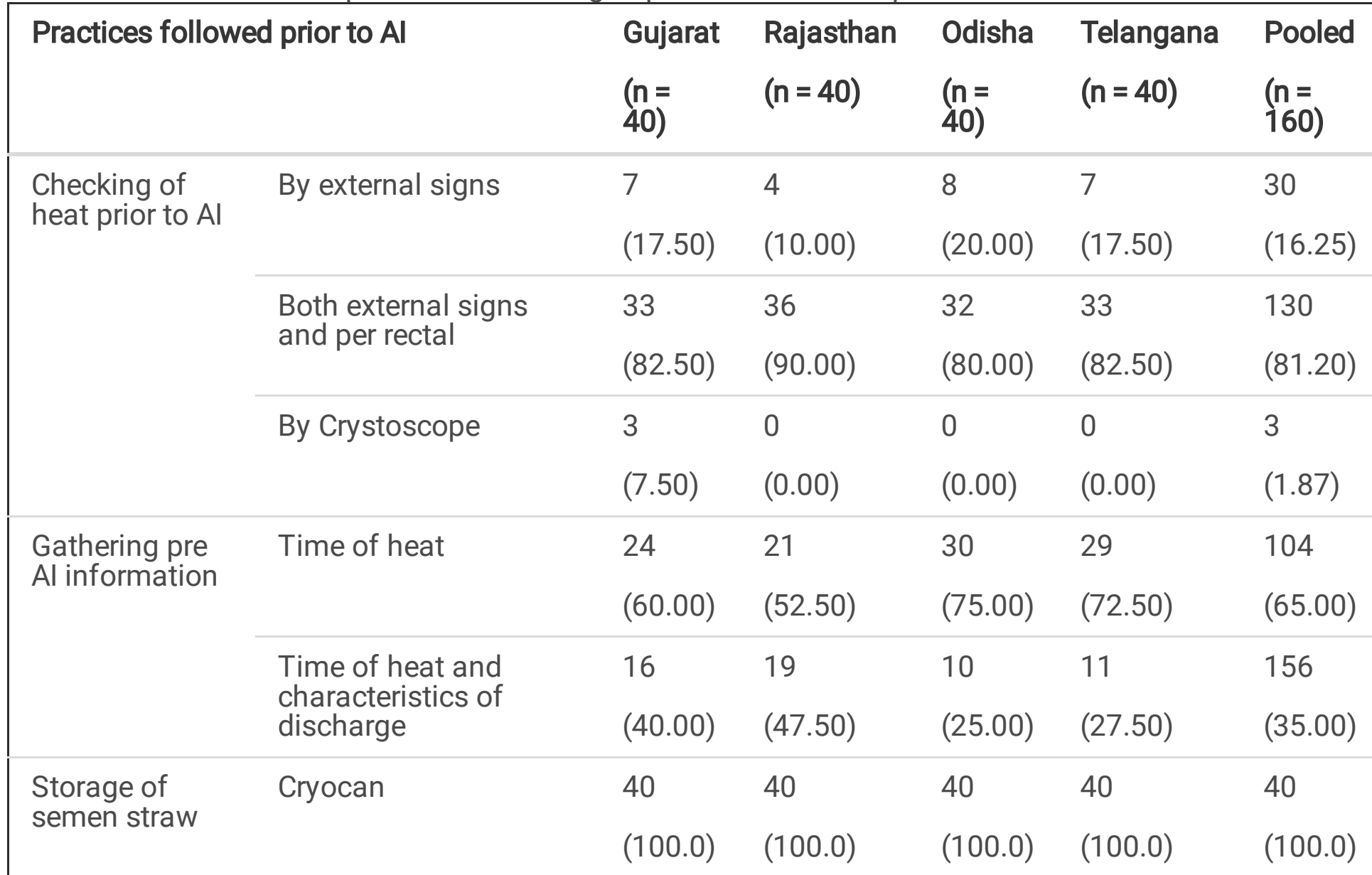

(Figures in parenthesis indicate percentage)

\subsubsection{Practices followed during actual execution of Artificial Insemination}

Table 3 presents the practices followed by paravets during Artificial Insemination. Results of table clearly indicate that cent percent of the respondents performed A.I. 12-18 hours after estrus. Majority (83.12\%) of paravets did thawing in pot containing hot water followed by some $(16.87 \%)$ who used both pot and water bath depending on the situation. Majority (95.62\%) of respondents were thawing the semen straw for $30-45$ seconds at $37^{\circ} \mathrm{C}$ followed by $1.90 \%$ thawing only for 10 second which is a wrong practice and leads to decrease in the probability of conception. Most of the paravets $(52.5 \%)$ used clean cloth for wiping of semen straw followed by $47.5 \%$ who used tissue paper. Cent percent of respondents were cutting the semen straw at $90^{\circ}$ angle. All of the respondents used gloves while performing A.I whereas Gumboots and apron were used by only 27.50 percent and 80 per cent of the paravets respectively. Maximum of paravets (91.20\%) deposited the semen in uterine body followed by horn (5.62\%) and cervix region $(3.12 \%)$. 
Table 3

Distribution of respondents according to the practices followed during to Artificial Insemination

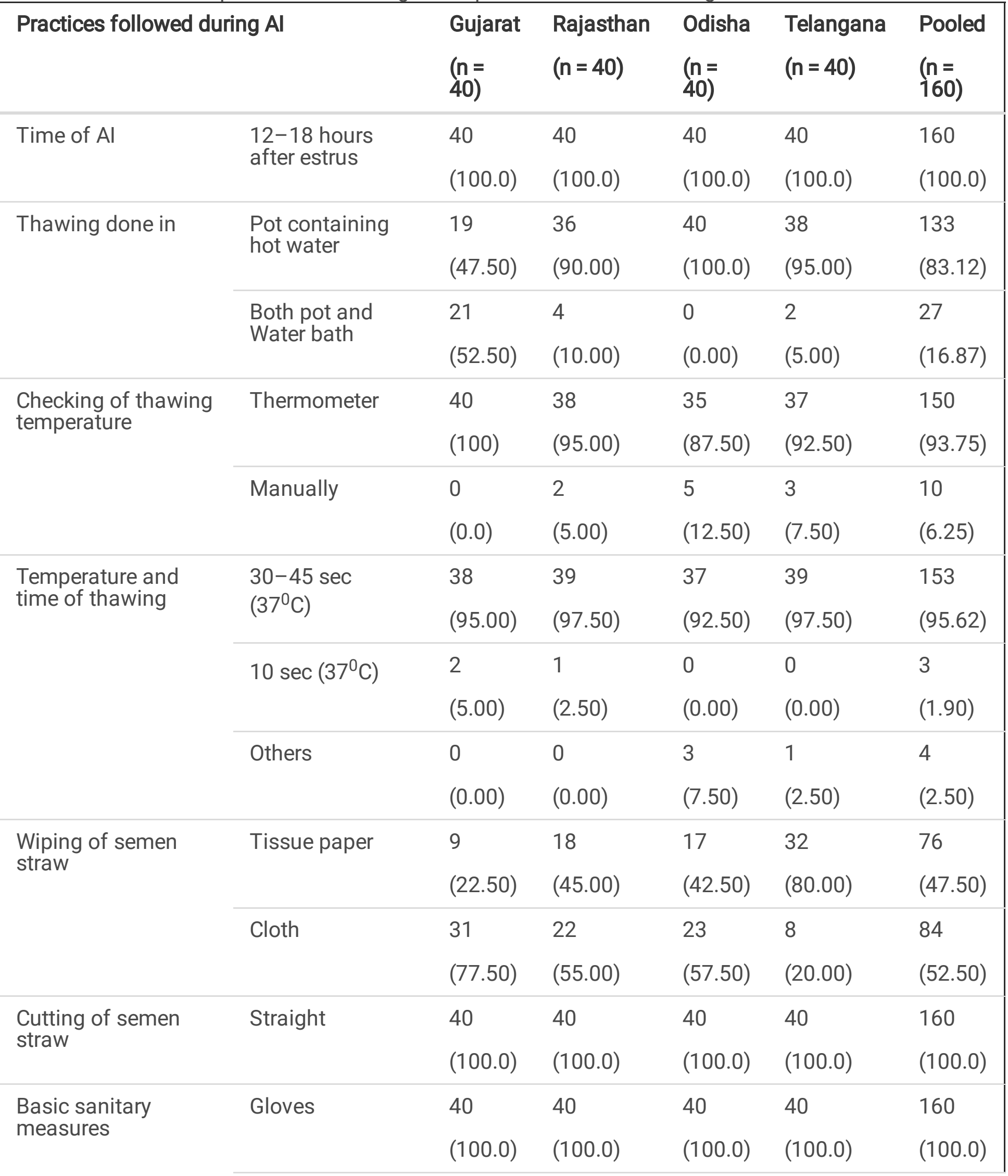




\begin{tabular}{|c|c|c|c|c|c|c|}
\hline \multicolumn{2}{|c|}{ Practices followed during Al } & $\begin{array}{l}\text { Gujarat } \\
(n= \\
40)\end{array}$ & $\begin{array}{l}\text { Rajasthan } \\
(n=40)\end{array}$ & $\begin{array}{l}\text { Odisha } \\
(n= \\
40)\end{array}$ & $\begin{array}{l}\text { Telangana } \\
(n=40)\end{array}$ & $\begin{array}{l}\text { Poolec } \\
(n= \\
160)\end{array}$ \\
\hline & Gumboots & 40 & 1 & 0 & 3 & 44 \\
\hline & & $(100)$ & $(2.50)$ & $(0.00)$ & $(7.50)$ & $(27.5)$ \\
\hline & Apron & 40 & 30 & 30 & 28 & 128 \\
\hline & & $(100)$ & $(75.00)$ & $(75.00)$ & $(40.00)$ & $(80.0)$ \\
\hline \multirow{6}{*}{$\begin{array}{l}\text { Deposition of semen } \\
\text { in }\end{array}$} & Uterine body & 38 & 31 & 38 & 39 & 146 \\
\hline & & $(95.00)$ & $(77.50)$ & $(95.00)$ & $(97.50)$ & $(91.2)$ \\
\hline & Horn & 0 & 9 & 0 & 0 & 9 \\
\hline & & $(0.00)$ & $(22.50)$ & $(0.00)$ & $(0.00)$ & $(5.62)$ \\
\hline & Cervix & 2 & 0 & 2 & 1 & 5 \\
\hline & & $(5.00)$ & $(0.00)$ & $(5.00)$ & $(2.50)$ & (3.12) \\
\hline
\end{tabular}

\subsubsection{Post-Al practices followed by the paravets}

Table 4 presents the practices followed by paravets after actual Artificial Insemination. Results of the table indicate that after the completion of $\mathrm{Al}$, follow up was done by $93.12 \%$ of the paravets while $6.88 \%$ of the respondents didn't perform the follow up. Monitoring for heat post calving was done by $86.87 \%$ of the paravets and record keeping for the Al was done manually by majority $(89.37 \%)$ of respondents followed by both manually and computerized $(10.63 \%)$. 
Table 4

Distribution of respondents according to the practices followed after Artificial Insemination

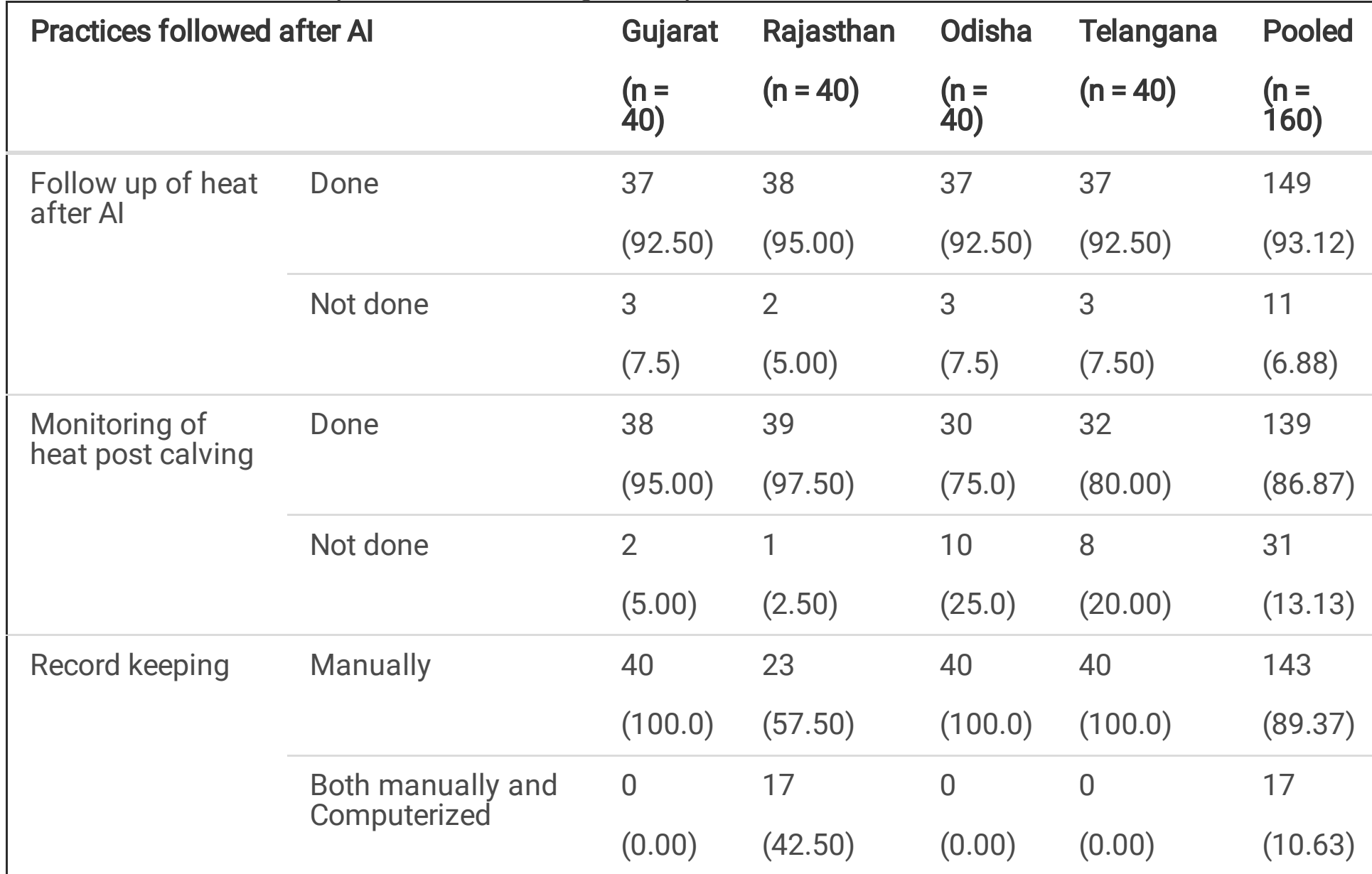

(Figures in parenthesis indicate percentage)

\subsection{Adoption gap in scientific recommended practices for Artificial Insemination among paravets}

Tables 5 and 6, respectively present the adoption score and gap in scientific recommended practices pertaining to artificial insemination among paravets. Results of the tables highlight that in as many as seven practices viz., gathering pre A.I. information, storage of semen straw, time of performing Al., thawing container, wiping of semen straw, cutting of semen straw and record keeping the adoption score was cent percent, thus gap was found to be Nil. Almost all the fourteen practices mentioned in the table no. 4 had high adoption score among paravets. From the data given in table no. 6 and Fig. 1, it is evident that maximum adoption gap (30.6\%) was seen in basic sanitary measures as the paravets were not maintaining basic sanitary practices viz., wearing of protective clothing during performing A.I. a significant difference $(p<0.01)$ was found among the four states in adopting basic sanitary measures which reveals that paravets of Gujarat showed nil adoption gap as compared to other three states who showed significantly higher gap in the above mentioned practice. About 13 percent of adoption gap was found in case of monitoring of heat post calving which further showed a visible significant difference among the states which depicts that the respondents of Gujarat and Rajasthan had comparatively lower adoption gap than the respondents of Odisha and Telangana. There was also an adoption gap of found 
in case of checking of heat prior to A.I. (8.00\%) followed by checking thawing temperature $(6.00 \%)$, follow up of heat after A.I. (7.00\%), appropriate temperature and time of thawing $(4.00 \%)$ and site of deposition of semen (3.00\%), though no significant differences found among the states.

Table 5

Adoption of Scientific Recommended Practices for Artificial Insemination among paravets

\begin{tabular}{|c|c|c|c|c|c|}
\hline \multirow{2}{*}{$\begin{array}{l}\text { Adoption score of Scientific } \\
\text { Recommended Practices for Al } \\
\text { (Average Percent score) }\end{array}$} & $\begin{array}{c}\text { Gujarat } \\
(n=40)\end{array}$ & $\begin{array}{l}\text { Rajasthan(n } \\
=40 \text { ) }\end{array}$ & $\begin{array}{l}\text { Odisha } \\
(n=40)\end{array}$ & $\begin{array}{l}\text { Telangana } \\
(\mathrm{n}=40)\end{array}$ & $\begin{array}{l}\text { Pooled } \\
(N=160)\end{array}$ \\
\hline & $\begin{array}{l}\text { Adoption } \\
\text { score }\end{array}$ & $\begin{array}{l}\text { Adoption } \\
\text { score }\end{array}$ & $\begin{array}{l}\text { Adoption } \\
\text { score }\end{array}$ & $\begin{array}{l}\text { Adoption } \\
\text { score }\end{array}$ & $\begin{array}{l}\text { Adoption } \\
\text { score }\end{array}$ \\
\hline Checking of heat prior to Al & 91.2 & 95 & 90.01 & 91.18 & 92 \\
\hline Gathering pre Al information & 100 & 100 & 100 & 100 & 100 \\
\hline Storage of semen straw & 100 & 100 & 100 & 100 & 100 \\
\hline Time of performing Al & 100 & 100 & 100 & 100 & 100 \\
\hline Thawing Container & 100 & 100 & 100 & 100 & 100 \\
\hline Checking thawing temperature & 100 & 95 & 87 & 92 & 94 \\
\hline Temperature \& time of thawing & 95 & 97 & 92 & 97 & 96 \\
\hline Wiping of semen straw & 100 & 100 & 100 & 100 & 100 \\
\hline Cutting of semen straw & 100 & 100 & 100 & 100 & 100 \\
\hline Basic sanitary measures & 100 & 58.6 & 57.8 & 61.1 & 69.4 \\
\hline Deposition of semen & 95 & 100 & 95 & 97 & 97 \\
\hline Follow up of heat after Al & 92 & 95 & 92 & 92 & 93 \\
\hline Monitoring of heat post calving & 95 & 97 & 75 & 80 & 87 \\
\hline Record keeping & 100 & 100 & 100 & 100 & 100 \\
\hline Overall adoption score & 97.7 & 95.54 & 92.05 & 93.57 & 94.91 \\
\hline
\end{tabular}


Table 6

Distribution of respondents according to gap in adopting various scientific recommended practices related to Al

\begin{tabular}{|c|c|c|c|c|c|c|}
\hline \multirow[t]{2}{*}{$\begin{array}{l}\text { Gap in Scientific } \\
\text { Recommended Practices for Al } \\
\text { (Average Percent score) }\end{array}$} & $\begin{array}{l}\text { Gujarat } \\
(n= \\
40)\end{array}$ & $\begin{array}{l}\text { Rajasthan } \\
(n=40)\end{array}$ & $\begin{array}{l}\text { Odisha } \\
(n= \\
40)\end{array}$ & $\begin{array}{l}\text { Telangana } \\
(n=40)\end{array}$ & $\begin{array}{l}\text { Pooled } \\
(n= \\
160)\end{array}$ & \multirow[t]{2}{*}{$\begin{array}{l}\text { F } \\
\text { Value }\end{array}$} \\
\hline & $\begin{array}{l}\text { Gap } \\
\text { score }\end{array}$ & Gap score & $\begin{array}{l}\text { Gap } \\
\text { score }\end{array}$ & Gap score & $\begin{array}{l}\text { Gap } \\
\text { score }\end{array}$ & \\
\hline Checking of heat prior to $\mathrm{Al}$ & $\begin{array}{l}8.8 \pm \\
3.04\end{array}$ & $5 \pm 2.4$ & $\begin{array}{l}10 \pm \\
3.20\end{array}$ & $8.8 \pm 3.04$ & $\begin{array}{l}8.1 \pm \\
1.4\end{array}$ & $0.54^{\mathrm{NS}}$ \\
\hline Gathering pre Al information & 0 & 0 & 0 & 0 & 0 & \\
\hline Storage of semen straw & 0 & 0 & 0 & 0 & 0 & \\
\hline Time of performing Al & 0 & 0 & 0 & 0 & 0 & \\
\hline Thawing Container & 0 & 0 & 0 & 0 & 0 & \\
\hline Checking thawing temperature & 0 & $5 \pm 3.5$ & $\begin{array}{l}13 \pm \\
5.3\end{array}$ & $8 \pm 4.2$ & $6 \pm 1.9$ & $1.86^{\mathrm{NS}}$ \\
\hline Temperature \& time of thawing & $5 \pm 3.5$ & $3 \pm 2.5$ & $8 \pm 4.2$ & $3 \pm 2.5$ & $4 \pm 1.6$ & $0.54^{\mathrm{NS}}$ \\
\hline Wiping of semen straw & 0 & 0 & 0 & 0 & 0 & \\
\hline Cutting of semen straw & 0 & 0 & 0 & 0 & 0 & \\
\hline Basic sanitary measures & $0^{\mathrm{a}}$ & $\begin{array}{l}41.4^{b} \pm \\
2.5\end{array}$ & $\begin{array}{l}42.2^{b} \\
\pm 2.2\end{array}$ & $38.9^{b} \pm 2.8$ & $\begin{array}{l}30.6 \pm \\
1.7\end{array}$ & $86.18^{\star *}$ \\
\hline Deposition of semen & $5 \pm 3.5$ & 0 & $5 \pm 3.5$ & $3 \pm 2.5$ & $3 \pm 1.4$ & $0.75^{\mathrm{NS}}$ \\
\hline Follow up of heat after Al & $8 \pm 4.2$ & $5 \pm 3.5$ & $8 \pm 4.2$ & $8 \pm 4.2$ & $7 \pm 2.0$ & $0.09^{N S}$ \\
\hline Monitoring of heat post calving & $\begin{array}{l}5^{\mathrm{a}} \pm \\
3.5\end{array}$ & $3^{a} \pm 2.5$ & $\begin{array}{l}25^{\mathrm{b}} \pm \\
6.9\end{array}$ & $20^{\mathrm{b}} \pm 6.4$ & $\begin{array}{l}13 \pm \\
2.7\end{array}$ & $4.5^{\star \star}$ \\
\hline Record keeping & 0 & 0 & 0 & 0 & 0 & \\
\hline
\end{tabular}

\section{Discussion}

In the current study, it is evident that there was a gap of $8.1 \%$ in case of heat detection prior to Al. Several studies on estrus behavior indicated about the silent heat without external signs in case of buffaloes [Roy and Prakash, 2009; Chohan et al., 1992) causing the major limitation in detecting heat leading to conception failure and thus, non-adoption of Al (Rajendra and Prabhakaran, 1992). It is also reported that conception failure may occur due to untrained technicians and incorrect time of insemination (Gizaw and Dima, 2016). Hence, Perfect A.I. execution and knowledge about heat detection tools like IVRI- 
Crystoscope are very important for increasing the conception rate and reducing the unwanted time gap between parturition and next pregnancy.

Similarly, the study also reported that majority were following proper thawing procedure whereas, few respondents $(6.0 \%$ and $4.0 \%)$ were handling the straw improperly as they used to check the temperature manually and the temperature and time of thawing according to them was wrong. Saacke (1974) Suggested that the temperature and time should be 35 degree $C$ and $30-60$ seconds. As per previous researches, the critical factors for reproductive performance encompass both herd-level and cow-level management factors and the herd level factors include cow management, methods of feeding, heat detection, semen handling (Lucy, 2001; Hudson et al., 2012). These deviations from SOPs may lead to reduced reproductive performance.

As per the current study, a visible gap (30.6\%) was found in adoption of basic sanitary measures among paravets while performing Al. This is in concordance with the results of (Hope et al., 2013) who reported that around $1 / 3$ rd of inseminators did not take adequate protective measures to ensure proper hygiene while performing Al. Previous research says that in case of cows, bacterial contamination during the execution of Al can suppress the pregnancy rates (Morrell, 2006). Furthermore, unhygienic practices during Al could also facilitate microbial colonization in the reproductive tract adversely affecting the fertility of cows (Givens and Marley, 2008; Dubuc et al., 2010) and can lead to ovarian malfunction, and reduced oocyte viability in dairy cows (Sheldon et al., 2014). These risks emphasise the need of maintaining proper hygiene during performing Al in cows. In a study the usefulness of using protective sheaths (PS) over the Al gun on pregnancies per Al was evaluated in dairy cows (Bas et al., 2009). Which showed an increase in pregnancies per Al in cows inseminated using the $\mathrm{Al}$ gun with sheath $(43.8 \pm 2.9 \%)$ compared to those inseminated without the sheath (32.3 $\pm 2.6 \%)$. An appropriate and hygienic Al practice is essential to improve reproductive performance in dairy cows. But, the critical steps like proper hygiene, appropriate semen handling, etc. are usually overlooked. Hence, basic sanitary measures such has washing of hands, wearing of gloves, protective clothing and gumboots are prerequisite for safe conduction of $\mathrm{Al}$ and will also prevent from invasion of microbes in reproductive tract of cattle, thus leading to sustainable improvement in reproductive performance.

From the results it is visible that the paravets were accurate with the standard time of insemination which is around mid-heat to late heat (12-18 hrs after onset of heat) as it provide optimal condition for fertilisation and improving embryo quality as well. This is contrary to the results of Garcia et al. (2001) who reported $\mathrm{Al}$ in cows at inappropriate times denoting serious heat detection errors. In a study conducted by Dalton et al. (2001), using HeatWatch technology, observed the association between time of insemination, fertility percentage and embryo quality in dairy cattle. In the study, cows were inseminated at $2.0 \mathrm{hrs}, 12.1 \mathrm{hrs}$ and $24.2 \mathrm{hrs}$ after onset of heat and concluded that insemination at $12 \mathrm{hr}$ after onset of oestrus provided a better condition in terms of maximising conception and simultaneously protecting the embryo qualities and this would agree with the report of Dransfield et al. (1998) who suggested 4 to $16 \mathrm{hrs}$ after onset of heat as the prime time for insemination. The quality of embryo may get impaired following late/delayed insemination as ovum gets aged (Dalton et al., 2001). 
The results revealed that majority of the paravets (91.7\%) were depositing semen in uterine body with few exception who used to deposit in uterine horn (5.62\%) and mid-cervix (3.12\%). The results go in line with several studies (Stewart and Melrose, 1952; Olds, 1953; Diskin et al., 2005) which showed minute differences in conception due to semen deposition in varied places viz., uterine horns, uterine body and mid-cervix which resulted in the acceptance of uterine body as site of depositing semen during $\mathrm{Al}$ in cattle. It is observed that there was a high significant effect $(p<0.01)$ of site of semen deposition on conception rate as uterine deposition of semen resulted in higher Conception (Nordin et al., 2004) and a significantly lower conception rate following cervical insemination (Macpherson, 1968). This would also agree with the study of Senger et al. (1988), which reported that the success rate for accurate placing of Al gun increased immediately after reskilling but relapsed again after 6 months gap. It has been also reported that more conceptions were achieved when Al was done by inseminator having longer formal training on Al unlike those with shorter training (Nordin et al., 2004) which suggests that retraining in regular interval is critically important. There are reports that around $50 \%$ of the inseminations were linked with factors like improper management or human error in the farm operations or during the Al service which negatively affected the reproductive performance (Garcia et al., 2001). It has been also reported that a significantly higher Conception rates/1st service $(P<0.05)$ was seen when inseminations were done by experienced inseminators (Garcia et al., 2001; Morton, 2004) which proves that experienced and trained person can perform better Al.

From the results, it is evident that adoption gap of $13 \%$ and $7 \%$ was seen in case of monitoring of heat post calving and monitoring of heat post Al. According to previous research, non-performance of post-Al heat detection leading to non-reporting of embryonic death and unobserved failed conception affects the insemination adversely (Garcia et al., 2001). Moreover, the major hindrances in profitable dairy husbandry are due to low conception to first services, more number of services per conception, delayed calving to $1 \mathrm{st}$ service interval, and improper and poor heat detection after Al (Alam and Ghosh, 1988; Shamsuddin et al., 2001).

\section{Conclusion}

Adoption gap of scientific recommended practices for Al reveals nil gap in as many as seven practices with a small gap of less than 10 per cent in five practices. The practices which showed adoption gap, though low, should be highlighted and necessary measures can be taken by SDAH to strengthen the capacity of paravets. A bit higher gap of 30.6 percent was found in basic sanitary measures for Al and $13 \%$ gap in monitoring of heat post calving. The state animal husbandry department needs to improve the input availability for para-vets for improving the efficiency of the Al services. Further, Crystoscope availability should be ensured as it is easy to use by paravets and farmers for heat detection. The paravets should be made aware about the importance of basic sanitary measures as wholesome proportion of paravets were not adopting basic sanitary measures despite of the availability of inputs. The paravets should be trained and made aware regarding the post Al heat detection so that the reproductive performance of cow can be monitored and necessary measure can be taken to combat any complications. More number of easily accessible platforms such as online websites, mobile apps in local 
languages need to be created for imparting knowledge and up-to-date information regarding artificial insemination. Further, zero gap in adoption of seven scientific practices reveals the strength and good working of the SDAH of the four states which needs to be highlighted for motivating the Para-veterinary professionals in other states as well.

\section{Declarations}

\section{Funding}

The author(s) received no specific funding for this work

\section{Conflicts of interest/Competing interests}

The authors declare no conflicts of interest.

\section{Ethics approval}

The manuscript does not contain clinical studies

\section{Consent to participate}

Before collection of socio-personal data, consent was taken from the human subjects.

\section{Consent for publication}

At the time of primary data collection, consent was taken from the human subjects to publish their data.

\section{Availability of data and material}

Primary data was collected in the present study through pre-tested questionnaire.

\section{Code availability}

For data analysis, Statistical Package for Social Sciences (SPSS) was used.

\section{Authors' contributions}

1. Dr. Pratikshya Panda was the Principal Investigator of the research work and dealt with all the budgetary and human resource allocations and sanctions.

2. Dr. Ruapsi Tiwari was the Chairperson, student advisory committee and research guide.

3. Dr. Pragya Joshi and Dr. Amandeep dealt with with data analysis and scripting.

4. Dr. Triveni Dutt was the co-advisor and member of student advisory committee

\section{References}


$20^{\text {th }}$ Livestock Census, 2020. Department of Animal Husbandry \& Dairying, Ministry of Fisheries, Animal Husbandry \& Dairying, Government of India, New Delhi

Alam, M.G.S. and Ghosh, A. 1988. Reproductive performance in cows: Its relation to parity and season. Bangladesh Veterinary Journal, 22: 51-61

Bas, S., Hoet, A., Rajala-Schultz, P., Sanders, D., and Schuenemann, G.M. 2009. Effects of using protective Al cover sheaths on fertility of lactating dairy cows. Reproduction Fertility and Development. 22:163-163

Chohan, K.R., Chaudhry, R.A., Iqbal, J. and Rahil, T. 1992. Comparative efficiency of male and androgenized female teaser for oestrus detection in buffaloes. Journal of Applied Animal Research, 2: $23-26$

Dalton, J.C., Nadir, S., Bame, J.H., Noftsinger, M., Nebel, R.L. and Saacke, R.G. 2001. Effect of time of insemination on number of accessory sperm, fertilization rate, and embryo quality in non-lactating dairy cattle. Journal of Dairy Science, 84: 2413-2418

Diskin, M.G., Pursley, R., Kenny, D.A., Mee, J.F., Corridan, D. and Sreenan, J.M. 2005. The effect of deep intrauterine placement of semen on conception rate in dairy cows. Proceedings Agricultural Research Forum, 14-15 March, Tullamore, Ireland, p. 29

Dransfield, M.B.G., Nebel, R.L., Pearson, R.E. and Warnick, L.D. 1998. Timing of insemination for dairy cows identified in estrus by a radiotelemetric estrus detection system. Journal of Dairy Science, 81: 1874-1882

Dubuc, J., Duffield, T. F., Leslie, K. E., Walton, J.S. \& Le Blanc, S.J. 2010. Definitions and diagnosis of postpartum endometritis in dairy cows. Journal of Dairy Science, 93(11): 5225-5233

Eklundh and Camilla. 2013. The use of artificial insemination in dairy farms in urban/periurban Kampala, Uganda: a study of knowledge, attitude and practices. Second cycle, A2E. Uppsala: SLU, Dept. of Clinical Sciences

Farmers' Manual, Dept. of Animal Husbandry, Dairying \& Fisheries, Government of India

Garcia, M., Goodger, W.J., Bennett, T. and Perera, B.M.A.O. 2001. Use of a standardized protocol to identify factors affecting the efficiency of artificial insemination services for cattle through progesterone measurement in fourteen countries. Proc. of final Research Co-ordination Meeting (IAEA-TECDOC- 1220) on 'Radioimmunoassay and related techniques to improve artificial insemination programmes for cattle reared under tropical and sub-tropical conditions', IAEATECDOC- 1220, p. 173-84. Vienna: IAEA Retrieved from: https://www.osti.gov/etdeweb/servlets/purl/20174537

Givens, M.D. and Marley, M.S. 2008. Pathogens that cause infertility of bulls or transmission via semen. Theriogenology, 70: 504-507 
Gizaw, T. and Dima, F.G. 2016. Assessment of problems and constraints associated with artificial insemination service in the two selected districts of Arsi zone. Journal of Harmonized Research in Medical and Health Sciences, 3(1): 14-37.

Hamdani, S.A. 2013. Role dynamics of para-veterinary professionals in relation to delivery of livestock health services. PhD. Thesis, IVRI, Izatnagar, Uttar Pradesh, India

Hope, A., Zimmermann, B. and Brightling, P. 2013. Al and semen handling in DIY herds. Accessed Oct. 9, 2018. http: / / www .harrisparkgroup .com .au/ wp -content/ uploads/ 2016/ 09/ InCalf -2013 -Al -Semen -handling -research -report -FINAL .pdf.

Hudson, C.D., Bradley, A.J., Breen, J.E. and Green, M.J. 2012. Associations between udder health and reproductive performance in United Kingdom dairy cows. Journal of Dairy Science, 95: 3683-3697

Ibrahim, N., Hailu, R. and Mohammed, A. 2014. Assessment of problems associated with artificial insemination service in selected districts of Jimma zone. Journal of Reproduction and Infertility, 5(2): $37-44$

Lawrence, F.G., Mutembei, H.M., Lagat, J., Mburu, J., Amimo, J. and Okeyo, A.M. 2015. Constraints to use of breeding services in Kenya. International Journal of Veterinary Sciences, 4(4): 211- 15

Lucy, M.C. 2001. Reproductive loss in high-producing dairy cattle: Where will it end? Journal of Dairy Science, 84:1277-1293

Macpherson, J.W. 1968. Semen placement effects on fertility in bovines. Journal of Dairy Science 51, 807

Morrell, J.M. 2006. Update on semen technologies for animal breeding Reproduction in Domestic Animals, 41: 63-67

Morton, J. 2004. Determinants of reproductive performance of dairy cows in commercial herds in Australia. PhD Thesis, University of Melbourne, Melbourne, Australia

Nordin, Y., Zaini, N. and Wan Zahari, W.M. 2004. Factors affecting conception rate in dairy cows under selected smallholder production system. Journal of Tropical Agriculture and Food Science, 32(2): 219227

Olds, D., Seath, D.M., Carpenter, M.C. and Lucas, H.L. 1953. Interrelationships between site of deposition, dosage, and number of spermatozoa in diluted semen and fertility of dairy cows inseminated artificially. Journal of Dairy Science 36: 1031-1035

Rajendra, K. and Prabhakaran, R. 1992. Current status and problems in feeding and breeding management of milch animals. Indian Dairyman XLIV(6): 274-76 
Roy, K.S. and Prakash, B.S. 2009. Plasma progesterone, oestradiol- $17 \beta$ and total oestrogen profiles in relation to oestrous behaviour during induced ovulation in Murrah buffalo heifers. Journal of Animal Physiology and Animal Nutrition (Berl), 93(4): 486-95

Saacke, R.G. 1974. Concepts in semen packaging and use. In Proceedings of the Eight Conference on Artificial Insemination of Beef cattle, 11-14 August, Toronto Canada, pp. 11-19

Senger, P.L., Becker, W.C., Davidge, S.T., Hillers, J.K. and Reeves, J.J. 1988. Influence of cornual insemination on conception rate in dairy cattle. Journal of Animal Science, 66: 3010-3016

Shamsuddin, M., Bhuian, M.M.U., Chanda, P.C., Alam, M.G.S. and Abedin, J. 1997. Fertility related factors at artificial insemination in cattle in Bangladesh. Proceed. Third Animal Scientific Conference, Bangaldesh Society for Veterinary Education and Research, Mymensingh, Bangladesh, 21-33

Shamsuddin, M., Bhuiyan, M.M.U., Sikder, T.K., Sugulle, A.H., Chanda, P.C., Alam, M.G.S. and Galloway, D. 2001. Constraints limiting the efficiency of artificial insemination of cattle in Bangladesh. In radioimmunoassay and related techniques to improve artificial insemination programmes for cattle reared under tropical and subtropical conditions. Proceeding of a final research co-ordination meeting organized by the joint FAO/IAEA. Division of nuclear techniques in food and Agriculture and held in Uppsala, Sweden.

Sheldon, I.M., Cronin, J.G., Healey, G.D., Gabler, C., Heuwieser, W., Streyl, D.J.J., Bromfield, A., Miyamoto, C., and Fergani, H. 2014. Dobson Innate immunity and inflammation of the bovine female reproductive tract in health and disease Reproduction, 148: R41-R51

Stewart, D.L. and Melrose, D.R. 1952. The comparative efficiency of intra-cervical and intra-uterine methods of insemination in the dairy cow. Veterinary Record, 64: 605.

Ybañez, A.P., Ybañez, R.H.D., Caindec, M.O., Mani, L.V., Abela, J.V., Nuñez, E.S., Royo, J.T. and Lopez, I.F.M. 2017. Profile and artificial insemination practices of technicians and the artificial insemination success rates in Leyte, Samar, and Biliran, Philippines (2011-2015). Veterinary World 10(2): 181-86

\section{Figures}




\section{Adoption gap of various practices related to AI among paravets}

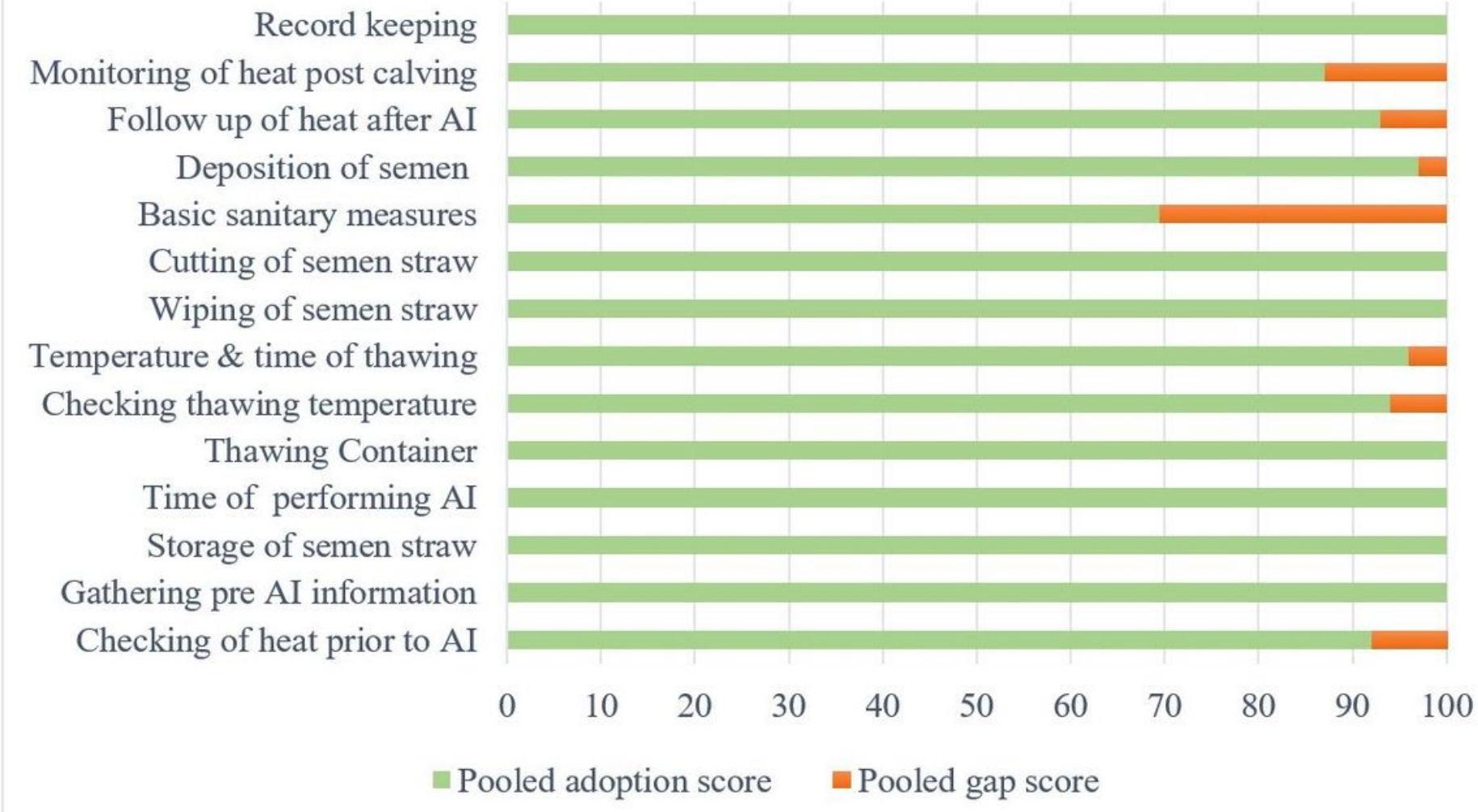

\section{Figure 1}

Overall gap in adoption of various practices related to $\mathrm{Al}$ 